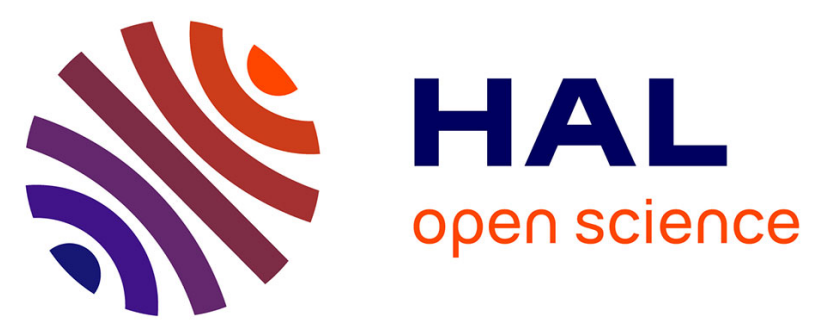

\title{
Bleeding complications during pregnancy and delivery in haemophilia carriers and their neonates in Western France: An observational study
}

\author{
Alice Nau, Benjamin Gillet, Benoît Guillet, Philippe Beurrier, Laurent
} Ardillon, Vincent Cussac, Sophie Guillou, Leela Raj, Marc Trossaert, Valérie Horvais, et al.

\section{To cite this version:}

Alice Nau, Benjamin Gillet, Benoît Guillet, Philippe Beurrier, Laurent Ardillon, et al.. Bleeding complications during pregnancy and delivery in haemophilia carriers and their neonates in Western France: An observational study. Haemophilia, 2020, 26 (6), pp.1046-1055. 10.1111/hae.14117 . hal02930160

\author{
HAL Id: hal-02930160 \\ https://hal.science/hal-02930160
}

Submitted on 20 Nov 2020

HAL is a multi-disciplinary open access archive for the deposit and dissemination of scientific research documents, whether they are published or not. The documents may come from teaching and research institutions in France or abroad, or from public or private research centers.
L'archive ouverte pluridisciplinaire HAL, est destinée au dépôt et à la diffusion de documents scientifiques de niveau recherche, publiés ou non, émanant des établissements d'enseignement et de recherche français ou étrangers, des laboratoires publics ou privés. 


\section{Bleeding complications during pregnancy and delivery in haemophilia carriers and their neonates in Western France: an observational study}

Alice $\mathrm{Nau}^{1}$, Benjamin Gillet ${ }^{2}$, Benoît Guillet ${ }^{3,4}$, Philippe Beurrier ${ }^{5}$, Laurent Ardillon ${ }^{6}$, Vincent Cussac $^{7}$, Sophie Guillou ${ }^{8,9}$, Leela Raj ${ }^{10}$, Marc Trossaërt ${ }^{2}$, Valérie Horvais ${ }^{2}$, Sophie Bayart ${ }^{3}$, Jérôme Potin $^{11}$, Johan Rose ${ }^{7}$, Laurent Macchi ${ }^{8,9}$, Francis Couturaud ${ }^{1,10}$, Karine Lacut ${ }^{1,10}$, Brigitte PanPetesch ${ }^{10,12}$

1 Département de Médecine Interne, Pneumologie et Médecine vasculaire, CHU Brest, Brest France

2 Centre de traitement de I'hémophilie, CHU Hôtel-Dieu Nantes, Nantes, France

3 Centre de traitement des maladies hémorragiques, CHU Rennes, Rennes, France

4 INSERM, U1085, IRSET, Université Rennes 1, Rennes, France

5 Centre de traitement de l'hémophilie, CHU Angers, Angers, France

6 Service d'hématologie - hémostase, Hôpital Trousseau, CHU Tours, Tours, France

7 Laboratoire d'hématologie, CH Le Mans, Le Mans, France

8 Service d'hématologie biologique, CHU Poitiers, Poitiers, France

9 INSERM, U1082, IRTOMIT, Université de Poitiers, Poitiers, France

10 EA3878, Université de Bretagne Occidentale, Brest, France

11 Service d'obstétrique, Hôpital Bretonneau, CHU Tours, Tours, France

12 Hémostase clinique, Service d’hématologie clinique, Centre de traitement des maladies hémorragiques, CHU Brest, Brest, France

\section{Running title: Bleedings in pregnant haemophilia carriers}

\section{Address for correspondence:}

Pr. Karine Lacut, Département de Médecine Interne, Pneumologie, et Médecine vasculaire, CHRU de Brest, 29609

Brest cedex, FRANCE.

e-mail: karine.lacut@chu-brest.fr; tel : +332981450 07; fax: +33298145008

\section{Author contributions:}

BPP had full access to all of the data in the study and takes responsibility for the integrity of the data and the accuracy of the data analysis. BPP designed and supervised the study, enrolled patients, analyzed and interpreted data, and participated in manuscript drafting. AN, KL, LR analyzed and interpreted data, and participated in manuscript drafting. AN and FC performed the statistical analyses. MT and VH participated to the administrative and technical support. $\mathrm{BGi}, \mathrm{BGu}, \mathrm{PB}, \mathrm{LA}, \mathrm{VC}, \mathrm{SG}, \mathrm{MT}, \mathrm{VH}, \mathrm{SB}, \mathrm{JP}, \mathrm{JR}$, and $\mathrm{LM}$ enrolled patients and critically revised the manuscript. All authors approved the final manuscript version. 


\section{Conflict of interest disclosures:}

B. Pan-Petesch reports having received travel support from Sobi, Roche, Takeda, CSL Behring, Novonordisk and fees for board memberships or symposia from Sobi, Roche, Takeda, CSL Behring, Novonordisk. B. Gillet declares he has acted as a paid consultant to Takeda, Novonordisk and Octapharma. L. Macchi reports having received fees for consulting from Bristol Myers Squibb, Daïchi Sankyo, Bayer-Healthcare, research grants from Bayer-Healthcare and Boehringer Ingelheim, and travel support from Baer Healthcare, Novonordisk, Octapharma, CSL Behring, Sobi, LFB biomédicaments, Pfizer. All other authors declare they have no competing interests.

Abstract: 241

Word count: 3175

Tables: 6

Figures: 1

Supplemental files: 1 


\section{Abstract:}

Background: Pregnancy, delivery and the postpartum period expose haemophilia carriers, as well as their potentially affected neonates to a high risk of haemorrhagic complications.

Objectives: To describe bleeding complications in haemophilia carriers and their newborns throughout pregnancy and postpartum and to identify potential factors increasing the risk of bleeding in this population.

Patients/Methods: The ECHANGE multicentre observational cohort study was conducted between January 2014 to February 2019 using the BERHLINGO database comprised of patients from seven French haemophilia centres.

Results: During the five years study period, a total of 104 haemophilia carriers and 119 neonates were included, representing 124 pregnancies and 117 deliveries. Thirty-five (30\%) bleeding events were observed, most of them (83\%) occurred during the postpartum period, and $37 \%$ were reported during the secondary postpartum. Neuraxial anaesthesia was not complicated by spinal haematoma. Three (2.5\%) neonates experienced cerebral bleeding. Caesarean section was associated with an increased risk of maternal bleeding in primary and secondary postpartum periods. Basal factor level $<0.4 \mathrm{IU} / \mathrm{ml}$ was also found to be associated with an increased risk of bleeding during secondary postpartum.

Conclusion: In our cohort, bleeding events occurred in more than a third of haemophilia carriers mainly in the postpartum period, and a significant portion of this bleeding occurred during the secondary postpartum. Haemophilia carriers warrant specific attention during primary and secondary postpartum, in particular in case of caesarean section and low basal factor level. The ECHANGE study is registered at clinicaltrials.gov identifier: NCT03360149

Keywords: Haemophilia carriers, pregnancy, postpartum, newborns, haemophilia A, haemophilia B. 


\section{Introduction}

Haemophilia is an X-linked disorder with an increase of haemorrhagic symptoms due to low or sometimes undetectable clotting factor, factor VIII (FVIII) in haemophilia A or factor IX (FIX) in haemophilia $B^{1}$. Due to the genetic presentation of the disorder, women may experience symptoms and carry the disorder to their children ${ }^{2}$.Women, referred as carriers, have usually median clotting factor levels of $0.6 \mathrm{IU} / \mathrm{ml}$ compared to $1.2 \mathrm{IU} / \mathrm{ml}$ in non-carriers ${ }^{3}$. However, a third of haemophilia carriers have basal clotting factor levels below $0.4 \mathrm{IU} / \mathrm{ml}$ and a third of haemophilia carriers present haemorrhagic symptoms, mainly muco-cutaneous and gynaecological bleedings events ${ }^{3,4}$. Nevertheless, no clear correlation exists between haemorrhagic symptomatology and basal levels of coagulation factors in carriers. In haemophilia carriers, pregnancy and delivery may be a high-risk haemorrhagic period deserving specific clinical attention. Their potentially affected neonate may be also at high risk of intracranial haemorrhage ${ }^{5}$. Despite the increase in FVIII levels during pregnancy until the third trimester, which could therefore reduce the haemorrhagic risk in carriers of haemophilia $A$, it might remain insufficient in some women ${ }^{6}$. FIX, on the other hand, remains stable throughout pregnancy, exposing carriers of haemophilia B to an increased risk of haemorrhagic complications. If undiagnosed as carriers, these women may remain untreated or poorly treated, exposing both the mother and newborn to an increased risk of morbidity and mortality. Carriers and their newborns therefore require complex, optimal and multidisciplinary care in a specialized centre. However, recent studies on the management of pregnancy and childbirth in haemophilia carriers are scarce, usually monocentric and findings are based on small sample sizes.

The multicenter observational study ECHANGE (Etude des pratiques professionnelles concernant la prise en charge des patientes conductrices d'hémophilie au cours de la grossesse, de l'accouchement et de leur nouveau-né) was conducted to describe bleeding complications in haemophilia carriers and their newborns throughout pregnancy and up to the first postpartum follow-up visit. Furthermore, this study sought to identify potential factors increasing the bleeding risk in this population. 


\section{Methods}

\section{Study design and population}

The data were extracted from an interregional database "BERHLINGO" (Base d'Etude et de Recherche en Hémostase pour Les INvestigateurs du Grand-Ouest) approved by French regulatory authorities for care and research studies. This database is completed by practitioners from the seven Western France Haemophilia Treatment Centres. Medical characteristics of each patient with a confirmed diagnosis of haemostatic disorder followed in one of this centre are collected and recorded in the database. To date, 2120 patients with haemophilia and 1007 women known as carrying haemophilia are included.

Consecutive carriers of haemophilia A or B, aged over 18 , with a documented pregnancy, including miscarriages and terminations, between January 1st 2014 and February 1st 2019 were selected. Carrier status was defined by a documented F8 or F9 mutation or by family history of haemophilia as defined by the World Federation of Haemophilia (i.e. daughters of a person with haemophilia, mothers of one son with haemophilia and who have at least one other family member with haemophilia, mothers of one son with haemophilia and who have a family member who is a known carrier of the haemophilia gene $)^{1}$. Multiple pregnancies in one carrier were included as separate events.

\section{Data collection}

Clinical and biological data were collected from the time of pregnancy diagnosis to the first postpartum visit ( 6 weeks post-delivery).

Baseline demographic and clinical data of all mothers were collected along with details regarding presentation and severity of haemophilia (based on genotype and/or basal factor level of related men with haemophilia ${ }^{1}$ ), hemorrhagic and obstetrical history. Positive bleeding phenotype in carriers was defined as presence of menorrhagia and/or one previous surgical bleeding complication among tonsillectomy, adenoidectomy, dental extraction and gynaecological surgery. Specificities regarding pre-planning and management of each pregnancy, labour and delivery, including knowledge of maternal carrier status, prenatal 
diagnosis, presence and type of analgesia, mode of delivery, and perineal injuries (i.e. episiotomy and perineal tear) were also recorded. The use of haemostatic supports as prophylactic treatment (i.e. tranexamic acid $1 \mathrm{~g}$ three times a day from delivery beginning to ten days, desmopressin single intravenous infusion of $0.3 \mu \mathrm{g} / \mathrm{kg}$ after umbilical cord clamping and FVIII or FIX concentrates intravenous infusion of $30-50 \mathrm{IU} / \mathrm{kg}$ with a target factor level greater than $0.5 \mathrm{IU} / \mathrm{ml}$ ) was collected. The last available measure of clotting factor level in the third trimester ( $\geq 34$ weeks of gestation), before delivery and before the use of any haemostatic support, was used to compare women with an a priori high risk of bleeding $(<0.5 \mathrm{IU} / \mathrm{ml})$ from those with an a priori low risk of bleeding $(\geq 0.5 \mathrm{lU} / \mathrm{ml})$.

Baseline clinical data, including mean gestational age at birth, birth weight, sex as well as details regarding diagnostic method, presence and severity of haemophilia and living status in the three days following birth, were collected for all neonates.

Maternal and neonatal bleeding complications were recorded separately. Maternal complications included bleeding during pregnancy, primary postpartum and secondary postpartum. Primary postpartum haemorrhage (PPH) was defined as blood loss $>500 \mathrm{ml}$ in the first 24 hours following birth. Secondary postpartum haemorrhage was defined as any bleeding or unusual bleeding for menstruation as reported by the woman or by the need for an emergency medical visit between the first 24 hours after delivery and the first postpartum visit (usually around six weeks after delivery). Neonatal bleeding complications included all severe bleedings events needing haemostatic treatment, in particular scalp haemorrhage, cephalohematoma, subgaleal hematoma and intracranial haemorrhage.

\section{Statistical analysis}

Descriptive statistics for continuous variable were presented as mean and standard deviations (SD). Categorical variables were expressed as number of patients and proportions (\%). To model the association between patient, pregnancy, labour and delivery characteristics and bleeding events in mothers, carriers with pregnancy-related bleeding were compared to carriers without bleeding. Univariate analyses allowed for selection of preliminary predictive variables for the multivariate model based on the following criteria: (i) a p-value $<0.2$ in the univariate analysis 
and (ii) a prevalence $>3 \%$. Correlations and interactions were systematically searched between selected variables prior to creating the multivariate model. All tests were two-sided and a pvalue of less than 0.05 was considered to be statistically significant. Missing data were not replaced for univariate and multivariate analyses. Statistical analyses were performed using SPSS software (version 20.0; SPSS, Inc.; Chicago, Illinois).

\section{Ethical approval}

The study protocol was approved by the ethics committee of Brest University Hospital, France. All participants received written information about the study and provided oral informed consent prior to inclusion.

\section{Results}

\section{Study population}

One hundred and ten haemophilia carriers who were pregnant between January 2014 and February 2019 were identified (Fig 1). Four women were excluded as they did not meet inclusion criteria and two were excluded due to insufficient data. Thus, a total of 104 haemophilia carriers were included in this study. During the observation period, 124 pregnancies occurred. Seven pregnancies resulted in premature termination due to miscarriage or abortion. Therefore, 117 deliveries occurred, and 119 babies were born (two twin pregnancies).

\section{Haemophilia carriers}

Characteristics of haemophilia carriers are presented in Table 1. In 40/98 (41\%) women with available data, basal factor level was $<0.4 \mathrm{IU} / \mathrm{ml}$.

\section{Pregnancies and prenatal diagnosis}

Details of planning and management of pregnancies are described in Table 2. Maternal carrier status was known before pregnancy in 113/120 (94\%) pregnancies with available data. Prenatal 
diagnosis was performed in 15 (12\%) pregnancies, including 2 pre-implantation genetic diagnosis, 9 chorionic villous samplings and 4 amniocenteses (Table 2). Abortions were practiced for medical reason in three carriers who were expecting an affected child.

\section{Labour, delivery and immediate postpartum}

Characteristics of labour, delivery and primary postpartum are detailed in Table 3. Among 23/117 (20\%) deliveries whose received planned preventive haemostatic support, 9/23 (39\%) had third trimester clotting factor level measure $<0,5 \mathrm{IU} / \mathrm{ml} 9 / 23$ (39\%) had previous bleeding phenotype and 2/23 (9\%) had history of PPH and 3/23 had third trimester clotting factor level between 0.5 and $0.8 \mathrm{IU} / \mathrm{ml}$. The preventive haemostatic support was planned in 9/14 (64\%) deliveries with third trimester factor level $<0.5 \mathrm{IU} / \mathrm{ml}$. Among the $5 / 14$ deliveries with factor level $<0.5 \mathrm{IU} / \mathrm{ml}$ but without haemostatic support, one presented caesarean bleeding complication. Of nine assisted deliveries, five were for female newborns and four for male newborns who had not been screened during pregnancy due to mild familial haemophilia. None of these four boys subsequently experienced mild haemophilia or bleeding complications. Statistically significant differences were observed regarding the type of analgesia, the use of planned preventive support, the mode of delivery and the perineal injuries between carriers with third trimester factor level $<0.5 \mathrm{IU} / \mathrm{ml}$ and those with $\geq 0.5 \mathrm{IU} / \mathrm{ml}$ (Table 3).

Neuraxial anesthesia was not complicated by spinal haematoma. Six of seven women with third trimester factor level $<0.5 \mathrm{IU} / \mathrm{ml}$ who received neuraxial or general anaesthesia, received also a planned preventive haemostatic support. Among the seven vaginal deliveries with third trimester factor level $<0.5 \mathrm{IU} / \mathrm{ml}$, all received factor replacement therapy but only one had an epidural anaesthesia. The four deliveries with third trimester factor level $\geq 0.5 \mathrm{IU} / \mathrm{ml}$ and planned preventive factor concentrates or desmopressin infusions presented a factor level close to $0.5 \mathrm{IU} / \mathrm{ml}$ (i.e. 0.51 or $0.52 \mathrm{IU} / \mathrm{ml}$ ) or a bleeding phenotype. They were all associated with epidural or spinal anaesthesia.

\section{Newborns}


Characteristics of neonates are presented in Table 4. All the 119 newborns remained alive three days following birth. Haemophilia screening was performed in $45 / 71(63 \%)$ male neonates on the first day after birth.

\section{Bleeding complications}

Thirty-five (30\%) bleeding events were recorded among 117 pregnancies and deliveries: six (17\%) during pregnancy, 16 (46\%) PPH, and 13 (37\%) secondary postpartum haemorrhages. Two of 16 PPH were massive and required blood transfusion. Three women had recurrent bleeding events during the same pregnancy (Supplementary e-Table1). Two of these patients had third trimester factor level $<0.5 \mathrm{IU} / \mathrm{ml}$ and required preventive haemostatic support during delivery.

Details on the births and characteristics of the three neonates having experienced a bleeding complication are listed in Supplementary e-Table 2. One having a mild haemophilia A presented a subependymal haemorrhage in the context of an extremely preterm twin birth. The second newborn, with severe haemophilia A, presented an intracranial haemorrhage on the first day of birth after normal vaginal delivery. The third child, with a severe haemophilia $A$, presented a subgaleal hematoma on the eighth day of life after an emergency caesarean section due to prolonged labour (Supplementary e-Table 2).

\section{Risk factors for maternal bleeding in haemophilia carriers}

A total of $17(16 \%)$ deliveries were complicated by a bleeding event during pregnancy or primary postpartum or both (Table 5). In multivariate analysis, cesarean section was the only variable independently associated with bleeding during delivery and primary postpartum (Supplementary e-Table 3).

Thirteen bleeding events (11\%) occurred during secondary postpartum (Table 6). In multivariate analysis, low basal level, caesarean section and age (younger women being at higher risk) were independently associated with bleeding risk during secondary postpartum (Supplementary eTable 3). 


\section{Discussion}

\section{Bleeding events}

In this cohort of haemophilia carriers, 35 bleeding events occurred among 117 pregnancies, deliveries and secondary post-partum (30\%), suggesting higher bleeding risks than in the general population ( 6 to $18 \%)^{6-13}$. Due to the ranging deficiencies in clotting factors, in haemophilia carriers, question often arise as to whether this population is exposed to increased haemostatic challenges throughout pregnancy. In agreement with our findings, previous studies have suggested that women with haemophilia have a risk of antenatal bleeding similar to that observed in the general population, estimated to affect 2 to $5 \%$ of pregnancies ${ }^{6-8}$. In our cohort, six antenatal haemorrhages occurred, corresponding to $5 \%$ of the pregnancies. Additionally, these six events remained minimal, did not require haemostatic support, and ceased spontaneously. Nevertheless, all antenatal haemorrhages were followed by subsequent bleeding events suggesting the need for careful monitoring after a first event. The postpartum period involves a high risk of haemorrhage. PPH occurred in $14 \%$ of pregnancies in our cohort (which is at the lower end of the current spectrum of findings from the literature, ranging from $11 \%$ to $51 \%)^{6,8-11}$. However, this incidence of $14 \%$ remained higher than in the general population (from $4 \%$ to $10 \%)^{10,11}$, which suggests a higher risk of haemorrhagic complications during this period among carriers, as already described in previous literature ${ }^{2,3,4,8,10}$. More than a third (37\%) of all 35 bleeding events occurred during the secondary postpartum period. In haemophilia A carriers, secondary postpartum haemorrhage may be a complication of particular significance, as clotting factor levels decrease rapidly on the third day postpartum to return to basal levels between 7 and 21 days, exposing these women to an increased bleeding risk particularly upon return of menses ${ }^{6,12,13}$. While secondary postpartum haemorrhage affects between 1 and $3 \%$ of deliveries in the general population, this complication was observed in $11 \%$ of pregnancies in our cohort. In all cases, these events presented as haemorrhagic first postpartum return of menses with several events requiring visits to the gynaecological emergency unit due to bleeding abundance ${ }^{14}$. Nevertheless, despite our particularly high incidence of secondary postpartum haemorrhage, this figure likely remains underestimated due to the habituation of these women to large volumes of blood loss during 
menstruation leading to decreased reporting rates ${ }^{12}$. Nonetheless, gynaecological bleeding complications must not to be ignored as they commonly lead to asthenia, iron deficiency and anaemia. These complications increase postpartum morbidity and often exert an important impact on women's quality of life, limiting daily living activities, reducing their ability to care for their children, and potentially leading to depression ${ }^{15-17}$. It therefore appears of great importance to increase awareness among haemophilia carriers regarding the risks associated with secondary postpartum haemorrhage.

\section{Pregnancy and delivery management}

Concerning the care of pregnant women, all patients with known maternal carrier status had a factor level measurement in their third trimester of pregnancy as recommended ${ }^{1,4,18}$. Most deliveries occurred in hospitals with haemophilia treatment centre and only two unintentional at-home birth. A majority of women had vaginal deliveries (77\%) with very low rates of instrumentation. In $50 \%$ of deliveries with third trimester factor levels $<0.5 \mathrm{IU} / \mathrm{ml}$, there was a caesarean section compared to $18 \%$ in deliveries with levels $\geq 0.5 \mathrm{IU} / \mathrm{ml}$ while caesarean section would increase the risk of bleeding in women ${ }^{19}$. However, five of these seven deliveries were made for unavoidable obstetric emergency indications. It is interesting to note that neuraxial anaesthesia was not complicated by spinal haematoma although three deliveries with third trimester factor level $<0.5 \mathrm{IU} / \mathrm{ml}$ received neuraxial anaesthesia without preventive haemostatic support. In contrast, six deliveries with third trimester factor level $<0.5 \mathrm{IU} / \mathrm{ml}$ whose received clotting factor level replacement therapy had not neuraxial anaesthesia. This practice seemed more severe than several guidelines ${ }^{9,17,18}$ which authorized anaesthesia covered by clotting factor replacement therapy. None of the seven carriers with third trimester factor levels $<0.5 \mathrm{IU} / \mathrm{ml}$ and a vaginal delivery had an episiotomy. This could suggest a reluctance to perform traumatic gestures in these women during deliveries.

\section{Risk factors for bleeding}

Results of the multivariate analysis revealed that caesarean section increased risk of bleeding in haemophilia carriers during primary postpartum period consistently with the current literature 
6,19-22 and also during the secondary postpartum period. Among 10 carriers who presented bleeding complications during caesarean section, nine of them had reached the cut-off of third trimester factor level $\geq 0.5 \mathrm{IU} / \mathrm{ml}$ spontaneously or after having received a factor concentrate replacement therapy. This could therefore suggest an increased risk of bleeding during caesarean section regardless of factor level and be an argument to promote vaginal birth against bleeding complications in carriers. However, although certain authors favour vaginal delivery, highlighting the bleeding risk incurred by mothers during caesarean sections, these recommendations are often accompanied by contraindications to assisted delivery which, nonetheless, is highly unpredictable and difficult to avoid in cases of complicated vaginal deliveries ${ }^{19}$. Furthermore, vaginal delivery does not exempt patients from risks of complications and may results in obstetric trauma, such as vulvar hematomas in mothers, and importantly exposes neonates to heighted risks of intra- and extra-cranial haemorrhage ${ }^{21}$. These arguments clearly depict the dilemma facing clinicians regarding mode of delivery in such patients and their potentially child with haemophilia ${ }^{19,21,22}$. In current clinical practice, the choice of mode of delivery remains based on a risk-benefit balance favouring vaginal delivery unless the patient presents with a significant obstetrical contraindication. Planned caesarean sections may be offered if the foetus is known to have haemophilia and when the mother is known to have presented obstetrical complications in the past ${ }^{1}$. Optimal mode of delivery should be thoroughly evaluated on a case-by-case basis with patient agreement and a multidisciplinary healthcare team.

Multivariate analyses also revealed that risk of bleeding complications during the secondary postpartum period was increased in case of low basal factor level $<0.4 \mathrm{IU} / \mathrm{ml}$. Because FVIII level decreases rapidly after delivery in haemophilia A carriers and FIX remains stable during pregnancy and delivery in haemophilia $B$ carriers ${ }^{6,12,13}$, this result highlights the importance to know basal factor level of carriers to prevent secondary postpartum bleeding complications. Three bleeding events were observed in neonates. In all three cases, the mother's carrying status was known and labour was spontaneous as classically recommended ${ }^{1,6,18}$. Two of the three children were born by emergency caesarean section due to risk of maternal-foetal complications unrelated to bleeding risk. Therefore, if caesarean section appears to be 
associated with an increased risk of bleeding in mothers, these two bleeding events in neonates could suggest caesarean section could not avoid bleeding risk in newborns as well, as some authors argue ${ }^{19,22}$.

\section{Strengths and limits}

Outstanding strengths of this study rest in the standardized collection of data on a large cohort size of 104 haemophilia carriers, 124 pregnancies, 117 births and 119 neonates, despite the restrained inclusion period of 5 years. The limited time-span of the study allowed for uniform assessment of current clinical practices considering that no major modifications in the guidelines regarding pregnancies of haemophilia carriers and their neonates were made from the time of inclusion (2014) to present. To our knowledge, to date, this is the largest study conducted over such a short time-span on haemophilia carriers and their neonates which exists in the literature. The main limitations were the sample size, and the limited number of neonatal haemorrhagic complications that did not allow bleeding risk factors analysis in this population.

\section{Conclusion}

In this observational study of haemophilia carriers, bleeding events occurred mainly in the postpartum period. In addition to primary postpartum haemorrhage already described in the current literature, this study highlighted the particular importance of monitoring and taking care of bleeding complications during secondary postpartum in haemophilia carriers. Caesarean section was found to be an independent predictor of postpartum related bleeding, and low basal factor level $<0.4 \mathrm{IU} / \mathrm{ml}$ was found to be associated with secondary postpartum bleeding. Our findings illustrate the dilemma which exists as regards the safest mode of delivery in haemophilia carriers and highlight the need for an individualized and multidisciplinary approach. Future larger prospective studies are required in order to compare current prevention and management strategies and determine best practices.

\section{ACKNOWLEDGEMENTS}


The authors acknowledge all members of the BERHLINGO working group. They are indebted to all patients who accepted participation in the study. 


\section{References}

1. Srivastava A, Brewer AK, Mauser-Bunschoten EP, et al. Guidelines for the management of hemophilia. Haemophilia. 2013;19(1):e1-e47.

2. Kadir RA, Economides DL, Braithwaite J, Goldman E, Lee CA. The obstetric experience of carriers of haemophilia. BJOG. 1997;104(7):803-810.

3. Plug I, Mauser-Bunschoten EP, Bröcker-Vriends AHJT, et al. Bleeding in carriers of hemophilia. Blood. 2006;108(1):52-56.

4. Shahbazi S, Moghaddam-Banaem L, Ekhtesari F, Ala FA. Impact of inherited bleeding disorders on pregnancy and postpartum hemorrhage. Blood Coagul Fibrinolysis. 2012;23(7):603-607.

5. Ljung RCR. Intracranial haemorrhage in haemophilia A and B. Br J Haematol. 2008;140(4):378-384.

6. Huq FY, Kadir RA. Management of pregnancy, labour and delivery in women with inherited bleeding disorders. Haemophilia. 2011;17 Suppl 1:20-30.

7. James $\mathrm{SL}$, Abate $\mathrm{D}$, Abate $\mathrm{KH}$, et al. Global, regional, and national incidence, prevalence, and years lived with disability for 354 diseases and injuries for 195 countries and territories, 1990-2017: a systematic analysis for the Global Burden of Disease Study 2017. The Lancet. 2018;392(10159):1789-1858.

8. Kadir RA, Davies J, Winikoff R, et al. Pregnancy complications and obstetric care in women with inherited bleeding disorders. Haemophilia. 2013;19 Suppl 4:1-10.

9. Chi C, Kadir RA. Inherited bleeding disorders in pregnancy. Best Pract Res Clin Obstet Gynaecol. 2012;26(1):103-117.

10. Stoof SCM, van Steenbergen HW, Zwagemaker A, et al. Primary postpartum haemorrhage in women with von Willebrand disease or carriership of haemophilia despite specialised care: a retrospective survey. Haemophilia. 2015;21(4):505-512.

11. Zwagemaker A, Gouw SC, Valk C, Ganzevoort W, Coppens M, Peters M. Postpartum haemorrhage in an unselected cohort of carriers of haemophilia. Haemophilia. 2018;24(4):e256-e259.

12. Chi C, Lee CA, Shiltagh N, Khan A, Pollard D, Kadir RA. Pregnancy in carriers of haemophilia. Haemophilia. 2008;14(1):56-64.

13. Chi C, Bapir M, Lee CA, Kadir RA. Puerperal loss (lochia) in women with or without inherited bleeding disorders. Am J Obstet Gynecol. 2010;203(1):56.e1-5. 
14. Combs CA, Murphy EL, Laros RK. Factors associated with postpartum hemorrhage with vaginal birth. Obstet Gynecol. 1991;77(1):69-76.

15. Kadir RA, Edlund M, Von Mackensen S. The impact of menstrual disorders on quality of life in women with inherited bleeding disorders. Haemophilia. 2010;16(5):832-839.

16. Olsson A, Hellgren M, Berntorp E, Baghaei F. Association between bleeding tendency and health-related quality of life in carriers of moderate and severe haemophilia. Haemophilia. 2015;21(6):742-746.

17. Hermans C, Kulkarni R. Women with bleeding disorders. Haemophilia. 2018;24(S6):29-36.

18. Pavord S, Rayment R, Madan B, et al. Management of Inherited Bleeding Disorders in Pregnancy: Green-top Guideline No. 71 (joint with UKHCDO). BJOG. 2017;124(8):e193e263.

19. Ljung R. The optimal mode of delivery for the haemophilia carrier expecting an affected infant is vaginal delivery. Haemophilia. 2010;16(3):415-419.

20. Oyelese Y, Ananth CV. Postpartum hemorrhage: epidemiology, risk factors, and causes. Clin Obstet Gynecol. 2010;53(1):147-156.

21. James $\mathrm{AH}$, Hoots $\mathrm{K}$. The optimal mode of delivery for the haemophilia carrier expecting an affected infant is caesarean delivery. Haemophilia. 2010;16(3):420-424.

22. Andersson NG, Chalmers EA, Kenet G, Ljung R, Mäkipernaa A, Chambost H. Mode of delivery in hemophilia: vaginal delivery and Cesarean section carry similar risks for intracranial hemorrhages and other major bleeds. Haematologica. 2019;104(10):21002106. 


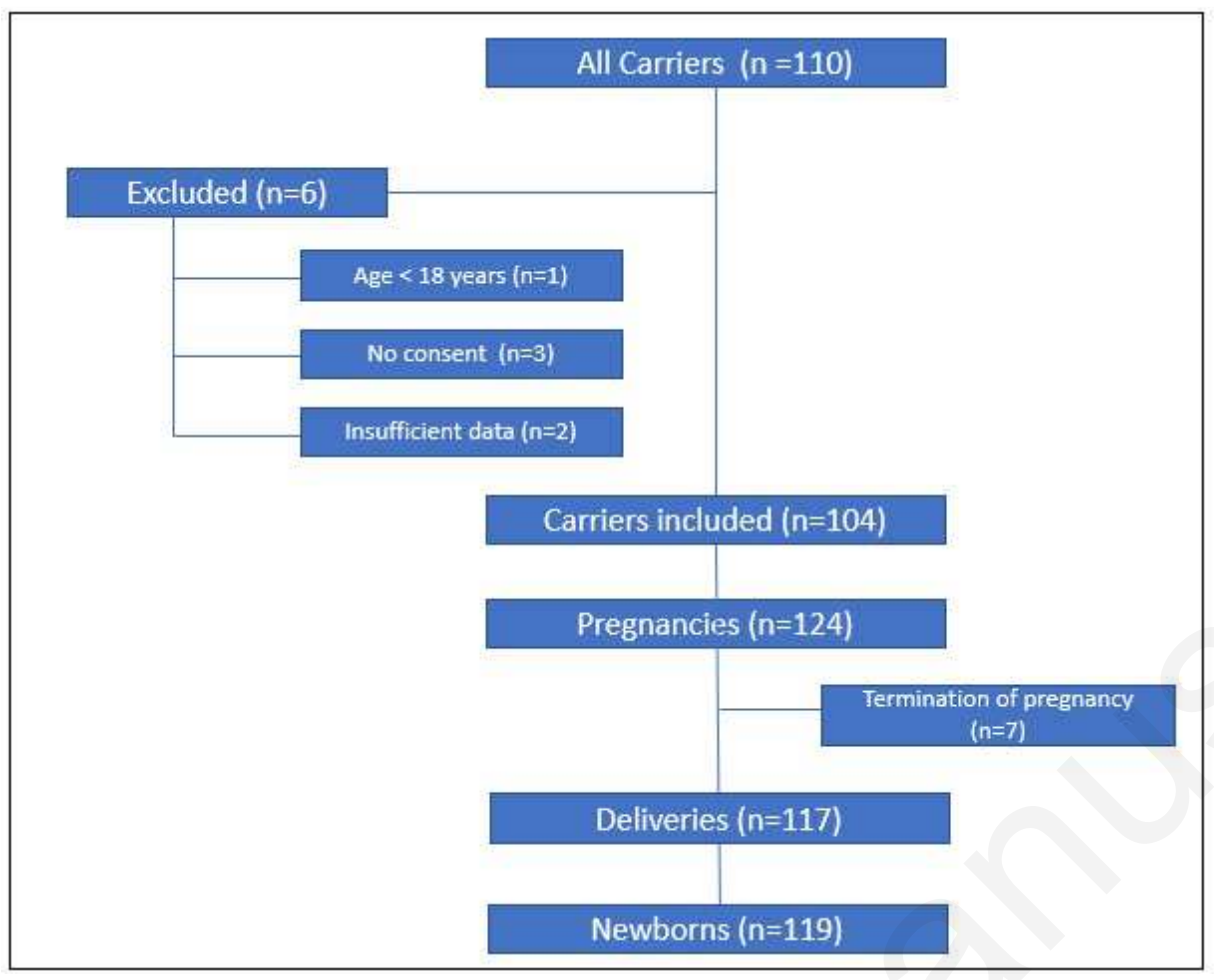

Figure 1: Flow chart of the study 
Table 1: Characteristics of haemophilia carriers

\begin{tabular}{|c|c|c|c|}
\hline & & & $\begin{array}{l}\text { Haemophilia carriers } \\
(n=104)\end{array}$ \\
\hline Age, mean $[ \pm S D]$ & & & 31 years $[ \pm 5]$ \\
\hline \multirow[t]{2}{*}{ Blood group, n (\%) } & \multicolumn{2}{|l|}{0} & $46(44 \%)$ \\
\hline & \multicolumn{2}{|l|}{ No-O } & $58(56 \%)$ \\
\hline \multirow{10}{*}{$\begin{array}{l}\text { Type of Haemophilia, } \\
n(\%)\end{array}$} & \multicolumn{2}{|l|}{ A } & $86(83 \%)$ \\
\hline & & Severe & $33(38 \%)$ \\
\hline & & Moderate & $10(12 \%)$ \\
\hline & & Mild & $42(49 \%)$ \\
\hline & & Unknown & $1(1 \%)$ \\
\hline & \multicolumn{2}{|l|}{ B } & $18(17 \%)$ \\
\hline & & Severe & $11(61 \%)$ \\
\hline & & Moderate & $2(11 \%)$ \\
\hline & & Mild & $4(22 \%)$ \\
\hline & & Unknown & $1(6 \%)$ \\
\hline Mutation, n (\%) & \multicolumn{2}{|l|}{ Known } & $83(80 \%)$ \\
\hline${\text { Basal Factor VIII level, mean }[ \pm S D]^{a}}^{a}$ & & $0.56 \mathrm{IU} / \mathrm{ml}[ \pm 0.33]$ \\
\hline 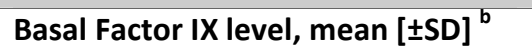 & \multicolumn{2}{|l|}{ 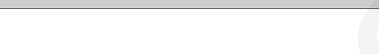 } & $0.52 \mathrm{IU} / \mathrm{ml}[ \pm 0.23]$ \\
\hline Low basal factor level, $\mathrm{n}(\%)^{\mathrm{c}}$ & \multicolumn{2}{|l|}{$<0.4 \mathrm{IU} / \mathrm{ml}$} & $40 / 98(41 \%)$ \\
\hline Bleeding phenotype, n (\%) & & & $48(46 \%)$ \\
\hline \multirow[t]{3}{*}{ Number of Pregnancies, $n$ (\%) } & \multicolumn{2}{|l|}{1} & $29(28 \%)$ \\
\hline & \multicolumn{2}{|l|}{$2-5$} & 72 (69\%) \\
\hline & \multicolumn{2}{|l|}{$>5$} & $3(3 \%)$ \\
\hline $\begin{array}{l}\text { History of primary postpartum } \\
\text { haemorrhage, } n(\%)\end{array}$ & & & $6 / 74(8 \%)$ \\
\hline \multicolumn{4}{|l|}{$\begin{array}{l}\text { a. missing data for } 3 \text { patients. } \\
\text { b. missing data for } 1 \text { patient. } \\
\text { c. missing data for } 6 \text { patients. }\end{array}$} \\
\hline
\end{tabular}


Table 2: Characteristics of pregnancies

\begin{tabular}{|c|c|c|}
\hline & & $\begin{array}{l}\text { Total pregnancies } \\
(n=124)\end{array}$ \\
\hline Known status of carrier, $n(\%)^{a}$ & & $113 / 120(94 \%)$ \\
\hline \multirow[t]{2}{*}{ Conception, n (\%) } & Natural & $118(95 \%)$ \\
\hline & Assisted & $6(5 \%)$ \\
\hline Singleton Pregnancy, n (\%) & & $122(98 \%)$ \\
\hline $\begin{array}{l}\text { Fetal sex determination through } \\
\text { maternal blood sampling, } \mathrm{n}(\%)\end{array}$ & & $21(17 \%)$ \\
\hline Prenatal Diagnosis, n (\%) & & $15(12 \%)$ \\
\hline \multirow[t]{3}{*}{$\begin{array}{l}\text { Type of prenatal diagnosis, } n(\%) \\
\text { b }\end{array}$} & $\begin{array}{l}\text { Pre-implantation genetic } \\
\text { diagnosis }\end{array}$ & $2(2 \%)$ \\
\hline & Chorionic villous sampling & $9(7 \%)$ \\
\hline & Amniocentesis & $4(3 \%)$ \\
\hline \multirow[t]{4}{*}{ Termination of pregnancy, $n$ (\%) } & & $7(6 \%)$ \\
\hline & Medical reason & $3(2 \%)$ \\
\hline & Voluntary termination & $3(2 \%)$ \\
\hline & Miscarriage & $1(1 \%)$ \\
\hline $\begin{array}{l}\text { Third trimester clotting factor } \\
\text { level }<0.5 \mathrm{IU} / \mathrm{ml}, \mathrm{n}(\%)^{\mathrm{c}}\end{array}$ & 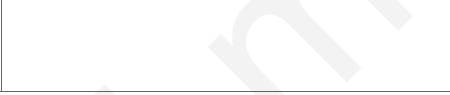 & $14 / 110(13 \%)$ \\
\hline \multicolumn{3}{|c|}{$\begin{array}{l}\text { a. missing data for } 4 \text { pregnancies. } \\
\text { b. cumulative total of antenatal diagnosis among carriers }\end{array}$} \\
\hline
\end{tabular}


Table 3: Characteristics of deliveries and post-partum periods

\begin{tabular}{|c|c|c|c|c|c|}
\hline & & \multirow{2}{*}{$\begin{array}{l}\text { Total } \\
\text { deliveries } \\
(n=117)\end{array}$} & \multicolumn{2}{|c|}{$\begin{array}{l}\text { Deliveries with third trimester } \\
\text { factor level }(n=110)^{a}\end{array}$} & \multirow[t]{2}{*}{ P value * } \\
\hline & & & $\begin{array}{c}<0,5 \mathrm{IU} / \mathrm{ml} \\
(\mathrm{n}=14)\end{array}$ & $\begin{array}{c}\geq 0,5 \mathrm{IU} / \mathrm{ml} \\
(\mathrm{n}=96)\end{array}$ & \\
\hline \multirow[t]{3}{*}{ Place of birth, $n(\%)$} & $\begin{array}{l}\text { University hospital } \\
\text { with HTC }\end{array}$ & $70(60 \%)$ & $11(79 \%)$ & $54(56 \%)$ & \multirow[t]{3}{*}{$P=0.131$} \\
\hline & Other & 45 (38\%) & $3(21 \%)$ & $40(42 \%)$ & \\
\hline & Home & $2(2 \%)$ & & $2(2 \%)$ & \\
\hline $\begin{array}{l}\text { Spontaneous } \\
\text { labour, n (\%) }\end{array}$ & & 87 (74\%) & $9(64 \%)$ & $73(76 \%)$ & $P=0.511$ \\
\hline \multirow[t]{5}{*}{$\begin{array}{l}\text { Type of analgesia, } \\
n(\%)\end{array}$} & $\begin{array}{l}\text { Epidural } \\
\text { anesthesia }\end{array}$ & $82 / 114(72 \%)$ & $4(29 \%)$ & 73/93 (79\%) & \multirow[t]{5}{*}{$P<0.001$} \\
\hline & Spinal anesthesia & $9 / 114(8 \%)$ & $1(7 \%)$ & $7 / 93(8 \%)$ & \\
\hline & General anesthesia & $6 / 114(5 \%)$ & $3(21 \%)$ & $3 / 93(3 \%)$ & \\
\hline & Local anesthesia & $1 / 114(1 \%)$ & 0 & $1 / 93(1 \%)$ & \\
\hline & None & $16 / 114(14 \%)$ & $6(43 \%)$ & 9/93 (11\%) & \\
\hline \multirow{5}{*}{$\begin{array}{l}\text { Use of preventive } \\
\text { haemostatic } \\
\text { support, } \mathrm{n}(\%)\end{array}$} & Anti-fibrinolytics & $11(9 \%)$ & $1(7 \%)$ & $10(10 \%)$ & \multirow[t]{5}{*}{$P<0.001$} \\
\hline & Desmopressin & $3(3 \%)$ & $1(7 \%)$ & $2(2 \%)$ & \\
\hline & Factor concentrate & $3(3 \%)$ & $2(14 \%)$ & $1(1 \%)$ & \\
\hline & $\begin{array}{l}\text { Factor concentrate } \\
\text { and anti- } \\
\text { fibrinolytics }\end{array}$ & $6(5 \%)$ & $5(36 \%)$ & $1(1 \%)$ & \\
\hline & None & $94(80 \%)$ & $5(36 \%)$ & $82(85 \%)$ & \\
\hline \multirow{6}{*}{$\begin{array}{l}\text { Mode of delivery, } n \\
(\%)\end{array}$} & Vaginal delivery & $90(77 \%)$ & $7(50 \%)$ & $79(82 \%)$ & \multirow[t]{6}{*}{$P=0.012$} \\
\hline & Normal & 81 (69\%) & $6(43 \%)$ & 71 (74\%) & \\
\hline & Assisted & $9(8 \%)$ & $1(7 \%)$ & $8(8 \%)$ & \\
\hline & Caesarian section & $27(23 \%)$ & $7(50 \%)$ & $17(18 \%)$ & \\
\hline & Elective & $8(7 \%)$ & $2(14 \%)$ & $5(5 \%)$ & \\
\hline & Emergency & $19(16 \%)$ & $5(36 \%)$ & $12(13 \%)$ & \\
\hline \multirow{3}{*}{$\begin{array}{l}\text { Type of assisted } \\
\text { vaginal delivery, } n \\
(\%)\end{array}$} & Spatulas & $3(3 \%)$ & 0 & $3(3 \%)$ & \\
\hline & Forceps & $4(3 \%)$ & 0 & $4(4 \%)$ & \\
\hline & Vacuum & $2(2 \%)$ & $1(7 \%)$ & $1(1 \%)$ & \\
\hline \multirow{3}{*}{$\begin{array}{l}\text { Perineal injuries, } \\
\mathrm{n}(\%)^{\mathrm{c}}\end{array}$} & Episiotomy & $14 / 90(16 \%)$ & 0 & $13 / 79(16 \%)$ & \multirow[t]{3}{*}{$P=0.033$} \\
\hline & Perineal tear & $44 / 90(50 \%)$ & $1 / 7(14 \%)$ & $40 / 79$ (51\%) & \\
\hline & Free & $32 / 90(36 \%)$ & $6 / 7(86 \%)$ & $26 / 79(33 \%)$ & \\
\hline \multirow{4}{*}{$\begin{array}{l}\text { Mode of placental } \\
\text { expulsion, } n(\%)^{d}\end{array}$} & Natural & $44 / 116(38 \%)$ & $5(36 \%)$ & $36 / 95(38 \%)$ & \multirow[t]{4}{*}{$P=0.048$} \\
\hline & $\begin{array}{l}\text { Oxytocin active } \\
\text { management }\end{array}$ & $44 / 116(38 \%)$ & $2(14 \%)$ & $40 / 95(42 \%)$ & \\
\hline & Manual removal & $2 / 116(2 \%)$ & 0 & $2 / 95(2 \%)$ & \\
\hline & $\begin{array}{l}\text { During the } \\
\text { Caesarean section }\end{array}$ & $26 / 116(22 \%)$ & $7(50 \%)$ & $17(18 \%)$ & \\
\hline $\begin{array}{l}\text { Number of days in } \\
\text { the maternity unit, } \\
\text { mean }[ \pm S D]\end{array}$ & & $4.9[ \pm 2.9]$ & $6[ \pm 3.6]$ & $4.7[ \pm 2.8]$ & $P=0.121$ \\
\hline
\end{tabular}




\begin{tabular}{|c|c|c|c|c|c|}
\hline \multirow[t]{7}{*}{$\begin{array}{l}\text { Contraception after } \\
\text { delivery, } n(\%)\end{array}$} & $\begin{array}{l}\text { Estrogen } \\
\text { progestogen oral } \\
\text { contraceptive }\end{array}$ & $23 / 113(20 \%)$ & $2(14 \%)$ & $21 / 92(23 \%)$ & \multirow[t]{7}{*}{$P=0.274$} \\
\hline & $\begin{array}{l}\text { Progestogen oral } \\
\text { contraceptive }\end{array}$ & $44 / 113(39 \%)$ & $6(44 \%)$ & $36 / 92$ (39\%) & \\
\hline & $\begin{array}{l}\text { Hormonal } \\
\text { intrauterine } \\
\text { devices }\end{array}$ & $5 / 113(4 \%)$ & 0 & $5 / 92(5 \%)$ & \\
\hline & $\begin{array}{l}\text { Copper } \\
\text { intrauterine } \\
\text { devices }\end{array}$ & $6 / 113(5 \%)$ & 0 & $4 / 92(4 \%)$ & \\
\hline & $\begin{array}{l}\text { Contraceptive } \\
\text { implant }\end{array}$ & $9 / 113(8 \%)$ & $3(21 \%)$ & $5 / 92(5 \%)$ & \\
\hline & Mechanical barrier & 1/113 (1\%) & & & \\
\hline & None & $25 / 113(22 \%)$ & $3(21 \%)$ & $21 / 92(23 \%)$ & \\
\hline $\begin{array}{l}\text { Breastfeeding, } \quad \mathrm{n} \\
(\%)\end{array}$ & & $63(54 \%)$ & $9(64 \%)$ & $53(55 \%)$ & $P=0.521$ \\
\hline
\end{tabular}

HTC: Haemophilia Treatment Center

${ }^{*} p$ value for the comparison between deliveries with third trimester factor level $<0.5 \mathrm{IU} / \mathrm{ml}$ and deliveries with third trimester factor level $\geq 0.5 \mathrm{IU} / \mathrm{ml}$

a. Third trimester clotting factor level was the last available value of clotting factor measured at 34 weeks of gestation or later in women with known status of carrier and no termination of pregnancy $(n=110)$.

${ }^{b}$. missing data for 3 deliveries.

c. among carriers who had vaginal delivery $(n=90)$.

$d$ missing data for 1 delivery.

e. missing data for 4 deliveries.

f. missing data for 4 deliveries. 
Table 4: Characteristics of neonates

Total Neonates

$(n=119)$

\begin{tabular}{|c|c|c|}
\hline${\text { Gestational age, mean }[ \pm S D]^{a}}^{a}$ & & $38.8[ \pm 2.3]$ \\
\hline Preterm birth, $n(\%)^{b}$ & & $10(9)$ \\
\hline Birth weights $(\mathrm{g})$, mean $[ \pm S D]^{c}$ & & $3315[ \pm 587]$ \\
\hline Sex, n (\%) & Male & $71(60 \%)$ \\
\hline $\begin{array}{l}\text { Screening of haemophilia in the males } \\
\text { neonates, } n(\%)\end{array}$ & Yes & $45(63 \%)$ \\
\hline \multirow{2}{*}{$\begin{array}{l}\text { Type of haemophilia screening, } \\
n(\%) \text { d }\end{array}$} & Cord blood sampling & $19 / 37(51 \%)$ \\
\hline & Venous blood sampling & $18 / 37(49 \%)$ \\
\hline Diagnosis of haemophilia, $n$ (\%) & Affected males & $31 / 71(44 \%)$ \\
\hline \multirow{8}{*}{$\begin{array}{l}\text { Type of Haemophilia, } \\
n(\%)\end{array}$} & A & $26(84 \%)$ \\
\hline & Severe & $13(52 \%)$ \\
\hline & Moderate & $1(4 \%)$ \\
\hline & Mild & $12(44 \%)$ \\
\hline & B & $5(16 \%)$ \\
\hline & Severe & $2(40 \%)$ \\
\hline & Moderate & $2(40 \%)$ \\
\hline & Mild & $1(20 \%)$ \\
\hline Breastfeeding, n (\%) & & $65(55 \%)$ \\
\hline
\end{tabular}

a. missing data for 2 neonates; results are expressed in weeks of gestation.

b. missing data for 2 neonates.

c. missing data for 2 neonates.

d. among newborn who were screened; missing data for 8.

e. among affected neonates. 
Table 5: Risk factors for bleeding during pregnancy and primary postpartum in univariate analysis

\begin{tabular}{|c|c|c|c|c|}
\hline & & $\begin{array}{l}\text { Bleeding } \\
\text { events } \\
(n=17)\end{array}$ & $\begin{array}{l}\text { Absence of } \\
\text { bleeding } \\
\text { events } \\
(n=100)\end{array}$ & $P$ value \\
\hline Age, years, mean $[ \pm S D]$ & & $31[ \pm 4]$ & $31[ \pm 4]$ & $P=1$ \\
\hline \multirow[t]{2}{*}{ Type of Haemophilia, $n$} & A & 12 & 86 & \multirow[t]{2}{*}{$P=0.148$} \\
\hline & B & 5 & 14 & \\
\hline $\begin{array}{l}\text { Low basal factor level }(<0.4 \\
\mathrm{IU} / \mathrm{ml}), \mathrm{n}^{\text {a }}\end{array}$ & Yes & 6 & 42 & $P=0.639$ \\
\hline Bleeding phenotype, $n$ & Yes & 7 & 49 & $P=0.549$ \\
\hline $\begin{array}{l}\text { History of primary } \\
\text { postpartum haemorrhage, } n^{b}\end{array}$ & Yes & 2 & 8 & $P=0.628$ \\
\hline Known status of carrier, $\mathrm{n}^{\mathrm{c}}$ & Yes & 17 & 90 & $P=0.379$ \\
\hline $\begin{array}{l}\text { Third trimester factor level } \\
<0.5 \mathrm{IU} / \mathrm{ml}, \mathrm{n}^{\mathrm{d}}\end{array}$ & Yes & 3 & 11 & $P=0.692$ \\
\hline \multirow[t]{2}{*}{ Type of Labour, $n$} & spontaneous labour & 8 & 79 & \multirow[t]{2}{*}{$P=0.009$} \\
\hline & Induced labour & 9 & 21 & \\
\hline Analgesia, $n^{e}$ & Yes & 17 & 81 & $P=0.124$ \\
\hline \multirow[t]{4}{*}{ Type of analgesia, $n^{f}$} & Epidural anaesthesia & 9 & 73 & \multirow[t]{4}{*}{$P=0.001$} \\
\hline & Spinal anaesthesia & 5 & 4 & \\
\hline & General anaesthesia & 3 & 3 & \\
\hline & Local anaesthesia & 0 & 1 & \\
\hline $\begin{array}{l}\text { Use of preventive } \\
\text { haemostatic support, } n\end{array}$ & Yes & 5 & 19 & $P=0.338$ \\
\hline \multirow[t]{4}{*}{ Mode of delivery, $n$} & Normal vaginal delivery & 5 & 76 & \multirow[t]{4}{*}{$P<0.001$} \\
\hline & Assisted vaginal delivery & 2 & 7 & \\
\hline & Elective caesarean section & 5 & 3 & \\
\hline & Emergency caesarean section & 5 & 14 & \\
\hline \multirow[t]{2}{*}{ Perineal injuries, $\mathrm{n}^{\mathrm{g}}$} & Yes & 5 & 53 & \multirow[t]{2}{*}{$P=0.072$} \\
\hline & No & 12 & 47 & \\
\hline \multirow[t]{4}{*}{ Placental expulsion, $\mathbf{n}^{\mathrm{h}}$} & Natural & 0 & 44 & \multirow[t]{4}{*}{$P<0.001$} \\
\hline & $\begin{array}{l}\text { Active management with } \\
\text { oxytocin }\end{array}$ & 6 & 38 & \\
\hline & Manual removal & 1 & 1 & \\
\hline & During caesarean section & 10 & 16 & \\
\hline $\begin{array}{l}\text { Number of days in the } \\
\text { maternity unit, mean }[ \pm S D]\end{array}$ & & $8[ \pm 6]$ & $4[ \pm 2]$ & $P<0.001$ \\
\hline \multicolumn{5}{|l|}{ missing data for 5 . } \\
\hline \multicolumn{5}{|l|}{${ }^{b}$ missing data for 3} \\
\hline \multicolumn{5}{|c|}{${ }^{d} 2$ home deliveries were excluded. } \\
\hline
\end{tabular}


e. missing data for 3 pregnancies.

${ }^{f}$. including carriers received analgesia $n=98$.

g. including carriers who had normal or assisted vaginal delivery $n=90$.

${ }^{h}$ missing data for 1 . 
Table 6: Risk factors for secondary postpartum bleeding in univariate analysis

\begin{tabular}{|c|c|c|c|c|}
\hline & & $\begin{array}{l}\text { Bleeding } \\
\text { events } \\
(n=13)\end{array}$ & $\begin{array}{l}\text { Absence of } \\
\text { bleeding } \\
\text { events } \\
(n=104)\end{array}$ & $P$ value \\
\hline \multicolumn{2}{|l|}{ Age, years, mean [ $\pm S D]$} & $27[ \pm 3]$ & $31[ \pm 5]$ & $P=0.006$ \\
\hline \multirow[t]{2}{*}{ Type of Haemophilia } & $A$ & 10 & 88 & \multirow[t]{2}{*}{$P=0.691$} \\
\hline & B & 3 & 16 & \\
\hline $\begin{array}{l}\text { Low basal factor level } \quad(<0.4 \\
\mathrm{IU} / \mathrm{ml}), \mathrm{n}^{\mathrm{a}}\end{array}$ & Yes & 10 & 38 & $P=0.008$ \\
\hline Bleeding phenotype, $n$ & Yes & 6 & 50 & $P=0.888$ \\
\hline Primiparous carriers, $n$ & Yes & 5 & 23 & $P=0.168$ \\
\hline $\begin{array}{l}\text { Bleeding complications during } \\
\text { pregnancies and deliveries, } n\end{array}$ & Yes & 4 & 13 & $P=0.095$ \\
\hline $\begin{array}{l}\text { Use of preventive haemostatic } \\
\text { support, } n\end{array}$ & Yes & 5 & 19 & $P=0.096$ \\
\hline \multirow[t]{4}{*}{ Mode of delivery, $n$} & Normal vaginal delivery & 6 & 75 & \multirow[t]{4}{*}{$P=0.025$} \\
\hline & Assisted vaginal delivery & 0 & 9 & \\
\hline & Elective caesarean section & 1 & 7 & \\
\hline & $\begin{array}{l}\text { Emergency caesarean } \\
\text { section }\end{array}$ & 6 & 13 & \\
\hline Perineal injuries, $\mathrm{n}^{\mathrm{b}}$ & $\overline{Y e s}$ & 5 & 50 & $P=0.550$ \\
\hline \multirow[t]{4}{*}{ Placental expulsion, $\mathrm{n}^{\mathrm{c}}$} & Natural & 4 & 40 & \multirow[t]{4}{*}{$P=0.049$} \\
\hline & $\begin{array}{l}\text { Active management with } \\
\text { oxytocin }\end{array}$ & 2 & 42 & \\
\hline & Manual removal & 0 & 2 & \\
\hline & During caesarean section & 7 & 19 & \\
\hline Contraception after delivery, $\mathrm{n}^{d}$ & Yes & 11 & 77 & $P=0.204$ \\
\hline \multirow[t]{6}{*}{$\begin{array}{l}\text { Type of contraception after } \\
\text { delivery, } \mathrm{n}\end{array}$} & $\begin{array}{l}\text { Oestrogen progestogen oral } \\
\text { contraceptive }\end{array}$ & 2 & 21 & \multirow[t]{6}{*}{$P=0.899$} \\
\hline & $\begin{array}{l}\text { Progestogen } \\
\text { contraceptive }\end{array}$ & 6 & 38 & \\
\hline & $\begin{array}{l}\text { Hormonal intrauterine } \\
\text { devices }\end{array}$ & 1 & 4 & \\
\hline & Copper intrauterine devices & 1 & 5 & \\
\hline & Contraceptive implant & 1 & 8 & \\
\hline & Mechanical barrier & 0 & 1 & \\
\hline Breastfeeding, $n$ & Yes & 7 & 56 & $P=1$ \\
\hline
\end{tabular}

a. missing data for 5 .

b. including carriers who had normal or assisted vaginal delivery $n=90$.

c. missing data for 1 .

d. missing data for 4.

e. among carriers who have contraception after delivery $n=88$. 